\title{
Inframe Mutation
}

National Cancer Institute

\section{Source}

National Cancer Institute. Inframe Mutation. NCI Thesaurus. Code C62199.

Any mutation occurring within the protein-coding region of a gene, and which results in a retention of the reading frame of the encoded protein. 